\title{
Design of PD Pasar Medan City Performance Measurement Using the Balanced Scorecard Method
}

\author{
Rika Puspita Dewi ${ }^{1}$, Nazaruddin Matondang ${ }^{2}$, Yeni Absah ${ }^{3}$ \\ ${ }^{1,2,3}$ Master of Management Universitas Sumatera Utara, Indonesia. \\ Corresponding Author: Rika Puspita Dewi
}

DOI: https://doi.org/10.52403/ijrr.20220252

\begin{abstract}
This study aims to determine the performance of PD Pasar Medan City using the Balanced Scorecard method using four perspectives, namely: (1) financial perspective, (2) customer perspective, (3) internal business process perspective, and (4) learning and growth perspective. This type of research is a case study. Data collection techniques used are interviews, documentation, observation and questionnaires whose samples consist of traders and employees. The data analysis techniques used are (1) financial perspective, namely financial ratio analysis, (2) customer perspective using Multi-attribute Attitude Model (MAM) analysis, (3) learning and growth perspective, (4) internal business process perspective using descriptive analysis. The results of data analysis are as follows: (1) The financial perspective shows an unfavorable condition, as seen from the Net Profit Margin (NPM) which is $>5 \%$ and the GPM (Gross Profit Margin) is $>8.3 \%$.

(2) The customer perspective shows a very good condition, because traders are satisfied with the services provided by PD Pasar Medan City

(3) The internal business process perspective shows a good condition, (4) The learning and growth perspective shows a very good condition, because employees are very satisfied with the existing performance at PD Pasar Medan City.
\end{abstract}

Keywords: Performance, Company, Balanced Scorecard

\section{INTRODUCTION}

The company was built with the aim to make a profit (profit) that is optimal. This view refers to a system of rating the performance of the traditional focuses only on the financial perspective. The leadership who managed to achieve the optimal profit will be considered a success and will obtain the reward (award) of the company. Up to now there are still many companies that use the measurement of the performance of the traditional performance measurement that are only focused on the financial perspective only. Performance measurement with the traditional system this causes the orientation of the company only on the short-term gains and tend to ignore the survival of the company in the long term. Performance measurement that focuses on the financial perspective only less able to measure the performance of the treasures of the invisible (intangible assets) and the treasures of the intellectual (human resources) of the company according to (Nugroho, 2018).

Performance measurement an overemphasis on the financial perspective often eliminate the other point of view is no less important. As such, customer satisfaction measurement and the process of adaptation in a change. So in a measurement of performance required a balance between performance measurement and financial performance measurement of non-financial. Such balance will be able to help the company in knowing and evaluating the overall performance (Atmadja et al, 2013:100)

If you want to win the competition in the information required new capabilities of the company's ability to manage the assets don't berwujudnya. This new ability 
Rika Puspita Dewi et.al. Design of PD Pasar Medan city performance measurement using the balanced scorecard method.

is more profitable company than to do both at the management of the physical assets or intangible. The management of assetsintangible assets that enable an organization to : 1) Build customer relationship by way of maintaining the loyalty of old customers and allows it to serve customer segments and new markets efficiently and effectively. 2) Introduce products and innovative services expected by the customer segment target. 3) Produce products and services of high quality at the level of prices and short wait times and 4) Spread the information technology, data base and system. ((Kaplan \& Norton, 1996)

To be able to realize it, then created a method of concept that measures the performance of the company using the four perspectives, namely financial perspective, financial perspective, internal business perspective, the perspective of growth and pembelajaransemuanya contained in the Balanced Scorecard (Dwivedi et al., 2021). According to (Safitri, 2016) definition of the four perspectives namely; 1) the financial Perspective is a measurement of financial performance that indicates the achievement of the implementation in realizing the goals, objectives, mission, and vision of the company's strategy so that it contributes on the improvement of the fundamental. Target strategy from a financial perspective is shareholder value, such as increasing the ROI (Return on Investment), corporate earnings growth, and decreasing the cost of production. 2) Perspective pelangganadalah company identify and define customer and segment pasamya. Target strategy from the Perspective of customers are increased confidence top customer products and services offered by the company and good relationship forged between the company and customers. 3) internal business Perspective is the process associated with the creation of goods and services, so that it can attract and retain customers in a market that is finally able to satisfy the expectations of shareholders. Target the strategy of the business process perspective this is organizational capital, such as increasing the quality of the service process to the customer, the computerization of the process of customer service, and implementation of infrastructure technology that allows services to customers. 4) learning and growth Perspective identifies the infrastructure that must be built company, to form the growth and development of the company in the long term. Goals strategies from learning and growth perspective is the HR (human resources) for example, the training of employees.

According to Kaplan and Norton (1992) in (Gawankar et al., 2015)the Balanced Scorecard (BSC) is a strategic management system powerful and balanced, which facilitate the implementation of the strategy, using measures to ensure that the vision and strategy of the company are implemented and achieved.

This study will be conducted in PD. Pasar Medan City which is one of Regional owned enterprises (BUMD) that is engaged in the services that manage the territory of the market, develop the market traders, and help stabilize prices and distribute goods and services smoothly. Performance measurement made during this time are still using a financial perspective. Here is a table of income PD Pasar Medan Cityon year 2015 to 2019 are presented in table 1

Table 1 Income Statement PD Pasar Medan City 2015-2019

\begin{tabular}{|c|c|c|c|c|c|}
\hline Description & 2015 & 2016 & 2017 & 2018 & 2019 \\
\hline Total Revenue & 42.495 .675 .764 & 40.962 .012 .657 & 41.973 .661 .567 & 47.108 .835 .341 & 47.759 .587 .587 \\
\hline Total Operating Expenses & 42.450 .998 .768 & 41.725 .911 .987 & 40.938 .879 .453 & 44.658 .529 .876 & 46.903 .190 .765 \\
\hline Income After Tax & 561.117 .357 & 403.449 .892 & 1.471 .657 .897 & 2.093 .040 .654 & 761.485 .728 \\
\hline
\end{tabular}

Based on table 1 it can be seen that In 2016 total revenue has decreased significantly Rp.1.533.663.107 but in 2018, the total revenue has increased very drastically Rp.5.135.173.774. In 2018 total operating expenses increased very 
Rika Puspita Dewi et.al. Design of PD Pasar Medan city performance measurement using the balanced scorecard method.

drastically $\mathrm{Rp}$ 2.244.660.889. This shows the expenditure PD Pasar Medan City exploded this year. In 2019 the PD Market is experiencing a decline in net income drastically Rp.761.485.728 of net profit in the year 2018. While in 2017 PD Pasar Medan City increased net profit of Rp.1.471.657.897 compared to the previous year

Thus, the financial condition of PD Pasar Medan City on year 2015 to 2019 fluctuated every year. This suggests that the PD Pasar Medan City has a weakness in perspective financial impact on the longterm benefits of the company.

According to the Local Regulations of the City of Medan No. 10 of 2014 stated that the Company's Market Area of the City of Medan serves as a tool of regional economic development and one of the sources of Local Revenue (PAD). According to (Sharma, 2009) Cigna Property and Casualty suffered a loss of one million dollars per day in 1992. To fix it they are using new strategies to implement the Balanced Scorecard. Five years later, Cigna earned a profit of $\$ 3$ billion.

In another study conducted by (Erawan, 2019) concluded that the ministry of finance of Indonesia has implemented a Balanced Scorecard for a decade and help the ministry of finance in linking strategic planning with the results area. The application of the Balanced Scorecard has increased the accountability of the performance of ministry of finance in a positive, proven from the results of the evaluation of the performance accountability of the Ministry of State Apparatus Empowerment. In 2016, the ministry of finance awarded " $A$ " (satisfactory) with the acquisition of the highest value $(83,79)$ among the 77 ministries and public institutions. In 2017 and 2018, the ministry of finance to obtain the score of the highest indicators of the components of performance planning, i.e. each 25,46 and 26,20 this is because the Balanced Scorecard highlights strategic planning. Not only increase the accountability of the performance, the Balanced Scorecard also contribute to the improvement of the bureaucracy.

In a study conducted by (Peris-Ortiz et al., 2019) at a University in Latin America concluded that the use of the Balanced Scorecard can improve the performance of the University like the rising of the journal publication, revenue from sales of products, registration and patent license.

In a study conducted in a hospital located diVietnam by (Pham et al., 2020) concludes that the use of three perspectives of the Balanced Scorecard, i.e., internal processes, financial and mission have the biggest positive influence and ensure statistical significance in this study. While aspects of the planning strategy, customer, learning and growth of employees showed a positive impact on the performance of the hospital.

\section{LITERATURE REVIEW \\ The Performance Of The Company}

Performance is an overview of the level of achievement of the implementation of an activity/ program/ wisdom in realizing the goals, objectives, mission, and vision of the organization as stated in the formulation of the strategic scheme (strategic planning) of an organization. In general, we can say that the performance is an achievement that can be achieved by the organization in a certain period (Sari \& Endang Dwi Retnani, 2015).

\section{Performance Measurement}

Performance measurement is a process of evaluation of progress towards the goals and targets that have been set previously, including the efficiency of penggungaan resources in producing goods or services; the results of the activity compared with the results to be achieved and effectiveness action in achieving the target (Kristiyanti, 2012). 
Rika Puspita Dewi et.al. Design of PD Pasar Medan city performance measurement using the balanced scorecard method.

\section{Balanced Scorecard}

The Balanced Scorecard is a powerful tool to measure the performance of the company which aims to measure the overall performance of the company, both financial and non-financial by using four perspectives: Financial Perspective, Customer Perspective, Internal Business Process Perspective, Learning and Growth Perspective (Zuniawan et al., 2020)

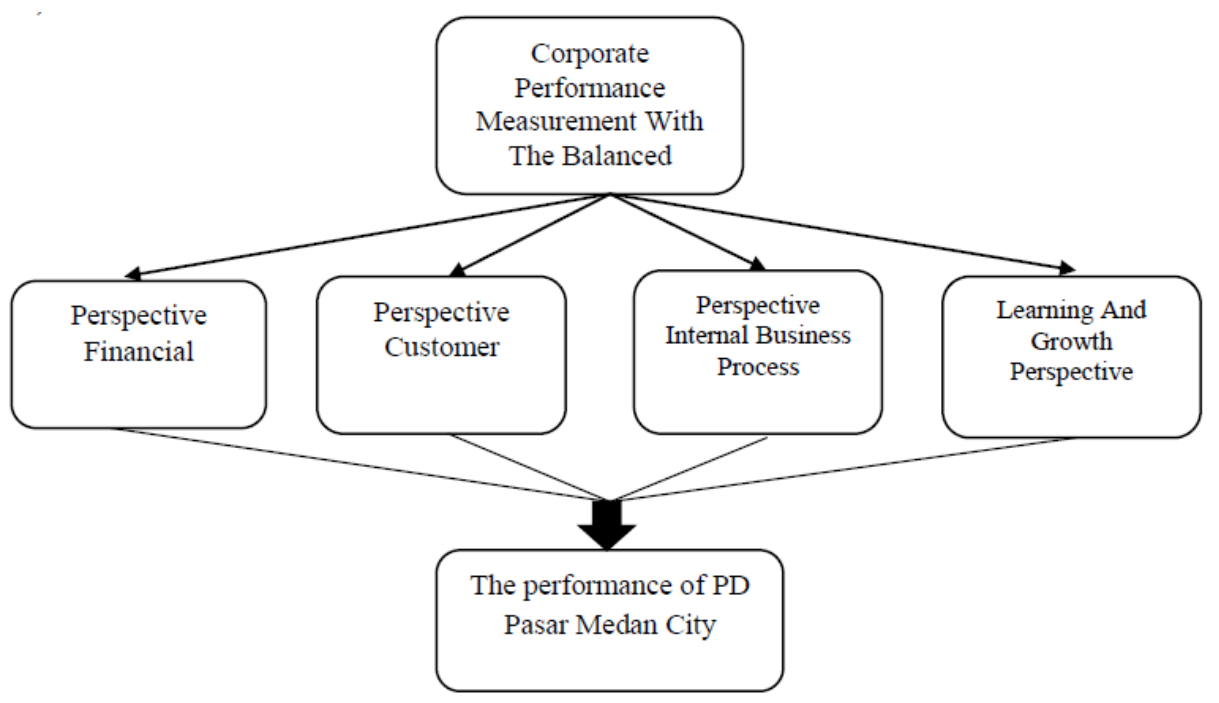

Figure 1. Conceptual Framework

\section{Description:}

\section{Financial Perspective}

The benchmarks used in financial perspective is the ratio of the economy, efficiency ratio, and the ratio of effectiveness.

\section{Customer Perspective}

The benchmarks used in the customer's perspective is customer satisfaction, customer profitability, retesi customer, and customer acquisition.

\section{Internal Business Process Perspective}

In this perspective the benchmark used is the operation process based on customer satisfaction.

\section{Learning And Growth Perspective}

In this perspective the yardstick used is employee satisfaction, staff retention, and employee productivity.

\section{MATERIAL AND METHODS}

This type of research is case study. According to (Rahardjo, 2017) a Case Study is a series of scientific activities carried out intensively, detail and depth of programs, events, and activities, both on an individual level, a group of people, institutions, or organizations to obtain in-depth knowledge about such events. Research methodology has an important role to help resolve the problem easily and purposeful. Need a model formulation of the problem to determine the problems of what is contained in the company, then the model is used to help resolve the issue.

The population in this study, the population, namely traders and employees Petisah Medan City. The sample of this Study using convenience sampling techniques, namely the method of sampling the respondents are the people who willingly offer themselves with the specific reason (Sinulingga, 2011). As the name implies, this method of selecting a sample from a population (of people or events) for which data are easily obtained by the researcher, namely: the Merchant of 30 respondents and Employees as much as 30 respondents so that the total sample of 60 samples of respondents.

The technique of Collecting Data using Interview techniques, namely by holding a q \& a with the Head of the Market Petisah Medan City on the company's history, facilities owned by the company, the location of the company, organizational 
structure, data traders and employees of the Market Petisah Medan City. The questionnaire is through the method of a survey addressed to the subject of research by compiling a list of questions about perspective contained in the Balanced Scorecard. Data collection techniques by providing a written statement given to the traders and employees of the Market Petisah Medan City. Documentation of data collection Techniques by looking at the archives of the company, such as: company history, financial statements, and other documents related to the research and Observation is a data collection Technique of the object of research by making observations on the company, related to: the company's facilities and the interaction between employees with Market traders Petisah Medan City.

Types and Sources of Data in this research using primary data and secondary data. According to (Kurniawan \& Puspitaningtyas, 2016) primary data is data that is collected by the researcher directly from the respondents. While the secondary data including data documentation published or used by the organization (Kurniawan \& Puspitaningtyas, 2016). Secondary Data in this research consist of the profit and loss in the year 2015-2019, used to measure performance from a financial perspective. Report the number of the potential of the market is open, close the lid and lifted the state of the s/d September 2020 is used to measure the performance from the customer perspective and internal business process perspective, and Report the number of employees year 2015-2019, used to measure the performance of the learning and growth perspective.

\section{RESULTS AND DISCUSSION Financial Perspective}

From a financial perspective can be seen starting from the NPM experience fluctuations. In the year 2015-2016 NPM PD Pasar Medan City decreased by 0.34 percent. year 2016-2018 increased for two years in a row. However from the year
2018-2019 NPM PD Pasar Medan City decreased by 2.85 percent. So also with GPM in the year 2015-2016 GPM PD Pasar Medan City decreased by $0.49 \%$. GPM years 2016-2018 increased for two years in a row. However from the year 2018-2019 GPM PD Pasar Medan City decreased by 0.39 percent.

\section{Customer Perspective}

In the perspective of customers state of PD Pasar City of Terrain said to be satisfied. The perspective of the customer is assessed through customer satisfaction. Can be seen from the results of the questionnaire above, the customer felt satisfied with the performance of PD Pasar Medan City with a value of 92,52 that are in the range of 81160 shows the results satisfied. This is because the PD Pasar Medan City provide clear information and understand what is needed by the customer. So that the resulting PD Pasar Medan City able to maintain a relationship with customers.

\section{Internal Business Process Perspective} Internal business process perspective, assessed through the innovation process, the process of the operation and the process of after-sales service. Of the innovation process PD Pasar Medan City meet the needs of the customers by way of revitalization and improvement of the market (shops, booths, facilities; mushola, toilet, parking and waste management, electricity, water and other. From the poses operation that is the result of innovation, the company put the personnel who are experts or advanced related to the innovation company so that work can more quickly and precisely. Then from the process of aftersales service company do the repair if it receives a complaint from the customer for damage that occurs in the PD Pasar like the tile shop leak, power outages, drainage is not smooth.

\section{Learning And Growth Perspective}

On the learning and growth perspective is assessed through the 
Rika Puspita Dewi et.al. Design of PD Pasar Medan city performance measurement using the balanced scorecard method.

capability of the company as well as motivation, authorization and restriction of authority. Of the capability of the company analysis has been done against some of the respondents obtained a value of 33,72 . If seen, these values are in the range $0-80$, which indicates that the results are very satisfied. It can be concluded that the PD Pasar Medan City give satisfaction for the employees, so that shows results very satisfied.

\section{CONCLUSIONS AND RECOMMENDATIONS CONCLUSIONS}

Based on the results of the research can be summed up as follows:

1. From a financial perspective the results obtained for the Net Profit Margin (NPM) are included in the category of less good because it is under the $>5 \%$, so also with the GPM (Gross Profit Margin) are in a category that is less good because it is below the 8.3 percent.

2. In the perspective of customers PD Pasar Medan City seen from the analysis, showing the results are satisfied. By performing the calculation of the overall method by using Multiatribute Attitude Model (MAM) shows the results of 92,52 and based on category included in the range are very satisfied. It can therefore be concluded that according to respondents a number of 30 customers, the performance of PD Pasar Medan City give satisfaction to the customer of the attributes of price, quality and time.

3. On the internal business process perspective PD Pasar Medan City seen from the analysis, showing good results. PD Pasar Medan City able to perform the innovation process, the process operation and process sales with better. Overall for the internal business process perspective shows good performance.

4. On the learning and growth perspective PD Pasar Medan City seen from the analysis, showing the results are very satisfied. By performing the calculation of the overall method by using Multiatribute Attitude Model (MAM) shows the results of 33,72 and based on pengkategoriannya included in the range are very satisfied. It can therefore be concluded that according to respondents a number of 30 employees performance PD Pasar Medan City give satisfaction to the employees of the attributes of communication, appreciation and support.

\section{RECOMMENDATIONS}

Suggestions researchers from the research that has been done is as follows:

1. Judging from the results of the analysis of questionnaires of employees still there is a statement that is far from the expectations of employees regarding leadership in providing opportunities in providing feedback and suggestions as well as a statement about the awards obtained staff for the achievement. Preferably PD Pasar Medan City pay more attention to this, because of the impact on the quality of employees and the performance of the company.

2. Seen from a financial perspective, preferably PD Pasar Medan City more careful if it will do the addition amount of the assets, because the addition of a number of assets affects the increase in cost and this resulted in an increased earnings be no maximum.

3. In the analysis of the questionnaire the customer still there is a statement that is far from the expectations of customers related to the employee in providing the information and understand the needs of the customers. Preferably PD Pasar Medan City provides space aspirations so that customer complaints can be channeled properly

Acknowledgement: None

Conflict of Interest: None

Source of Funding: None 
Rika Puspita Dewi et.al. Design of PD Pasar Medan city performance measurement using the balanced scorecard method.

\section{REFERENCES}

1. Dwivedi, R., Prasad, K., Mandal, N., Singh, S., Vardhan, M., \& Pamucar, D. (2021). Performance evaluation of an insurance company using an integrated balanced scorecard (bsc) and best-worst method (bwm). Decision Making: Applications in Management and Engineering, 4(1), 33-50. https://doi.org/10.31181/dmame2104033d

2. Erawan, I. G. A. (2019). Journal of Public Administration Studies Implementation of Balanced Scorecard in Indonesian Government Institutions : A. 4(2), 64-71.

3. Farooq, A., \& Hussain, Z. (2011). Balanced scorecard perspective on change and performance: A study of selected Indian companies. Procedia - Social and Behavioral Sciences, 24, 754-768. DOI: https://doi.org/10.1016/j.sbspro.2011.09.043

4. Gawankar, S., Kamble, S. S., \& Raut, R. (2015). Performance Measurement using Balance Score Card and its Applications: A Review. Journal of Supply Chain Management Systems, 4(3). https://doi.org/10.21863/jscms/2015.4.3.009

5. Hasriani, Nasruddin, \& Hidayat, M. (2018). Analisis Kinerja Stai Al-Azhar Gowa dengan Pendekatan Balanced Scorecard. Jurnal Mirai Management, vol.3 no.2(2),21. https://journal.stieamkop.ac.id/index.php/mi rai/article/view/265/139

6. Imelda. (2004). Implementasi Balanced Scorecard Pada Organisasi Publik. Jurnal Akuntansi Dan Keuangan, 6(2), 106-122122. https://doi.org/10.9744/jak.6.2.pp.106122

7. Kaplan, R., \& Norton, D. (1996). The balanced scorecard: Translating strategy into action. In Long Range Planning (Vol. 30, Issue 3). https://doi.org/10.1016/s00246301(97)80925-9

8. Kristina, D. (2010). Pengukuran Kinerja Perusahaan Dengan Metode Balanced Scorecard (Studi kasus PT Kredo Segitiga Utama cabang Yogyakarta. 1-20.

9. Kristiyanti, M. (2012). Peran Indikator Kinerja Dalam Mengukur Kinerja Manajemen. Majalah Ilmiah informatika,3(3), 103-123. http://www.unaki.ac.id/ejournal/index.php/ majalah-ilmiah informatika/article/view/79

10. Kurniawan, A. W., \& Puspitaningtyas, Z. (2016). Metode Penelitian Kuantitatif.

11. Nilamsari, D. P. (2018). Pengukuran Kinerja Tenaga Profesional Pada Organisasi
Jasa (Studi Kasus Kotabahasa Salatiga). Jemap, 1(1), 129. https://doi.org/10.24167/jemap.v1i1.1588

12. Nugroho, P. S. (2018). Perancangan Balance Scorecard Sebagai Instrumen Pengukuran Kinerja Pada Cv. Jadi Jaya Makmur Semarang. Jurnal Ilmu Manajemen Dan Akuntansi Terapan (JIMAT), 9(1), 7988.

13. Peris-Ortiz, M., García-Hurtado, D., \& Devece, C. (2019). Influence of the balanced scorecard on the science and innovation performance of Latin American universities. Knowledge Management Research and Practice, 17(4), 373-383. https://doi.org/10.1080/14778238.2019.156 9488

14. Pham, C. D., Vu, S. T., Pham, Y. T. K., \& $\mathrm{Vu}$, N. T. (2020). Evaluating performance of Vietnamese public hospitals based on balanced scorecard. Journal of Asian Finance, Economics and Business, 7(6), 339-349.

https://doi.org/10.13106/JAFEB.2020.VOL 7.NO6.339

15. Rahardjo, M. (2017). Studi kasus dalam penelitian kualitatif:konsep dan prosedurnya.11(1), 92-105.

16. Ributari Nurgahayu, E., \& Dwi Retnani, E. (2015). Penerapan Metode Balanced Scorecard Sebagai Tolok Ukur Pengukuran Kinerja Perusahaan. Jurnal Ilmu \& Riset Akuntansi, 4(10), 1-16.

17. Rinati, I. (2008). Pengaruh Net Profit Margin (NPM), Return On Assets (ROA) dan Return on Equity (ROE) terhadap Harga Saham pada Perusahaan yang Tercantum Dalam Indeks LQ45. 1-12.

18. Safitri, M. (2016). analisis pengukuran kinerja perusahaan dengan metode balanced scorecard pada pt. perkebunan nusantara vh (persero) unit musi landas.

19. Sari, A. P., \& Endang Dwi Retnani. (2015). Penerapan Balanced Scorecard sebagai Alat Pengukuran Kinerja pada Rumah Sakit Islan Surabaya. Jurnal Ilmu \& Riset Akuntansi, 4(11), 1-24.

20. http://www.investopedia.com/terms/b/balan cedscorecard.asp

21. Sharma, A. (2009). Menerapkan Balance Scorecard untuk Pengukuran Kinerja. 7-17.

22. Solichah, A. (2015). analisis balanced scorecard sebagai sarana pengukuran kinerja perusahaan (Studi Kasus pada Pabrik Gula Pesantren Baru Kediri). Jurnal Administrasi 
Rika Puspita Dewi et.al. Design of PD Pasar Medan city performance measurement using the balanced scorecard method.

Bisnis S1 Universitas Brawijaya, 27(2), 86365.

23. Tanjung, M. (2018). analisis kinerja perusahaan dengan metode balanced scorecard pada pt. ria busana cabang iskandar muda medan.

24. Wargadinata, E. (2017). Kualitas Pengukuran Kinerja Organisasi Publik. Sosiohumaniora, 19(2), 9.

25. Yusup, F. (2018). Uji Validitas dan Reliabilitas. Jurnal Tarbiyah: Jurnal Ilmiah Kependidikan, 7(1), 17-23. https://jurnal.uinantasari.ac.id/index.php/jtjik/article/downlo $\mathrm{ad} / 2100 / 1544$
26. Zuniawan, A., Julyanto, O., Suryono, Y. B., \& Ikatrinasari, Z. F. (2020). implementasi metode balanced scorecard untuk mengukur kinerja di perusahaan engineering (Study Case PT. MSE). Journal Industrial Servicess, 5(2), 251-256. https://doi.org/10.36055/jiss.v5i2.8008.

How to cite this article: Rika Puspita Dewi, Nazaruddin Matondang, Yeni Absah. Design of PD Pasar Medan city performance measurement using the balanced scorecard method. International Journal of Research and Review. 2022; 9(2): 411-418. DOI: https://doi.org/ 10.52403/ijrr.20220252

$* * * * * *$ 